\title{
Consensus on the principles of physical development monitoring in children, possible or not?
}

\author{
Czy możliwy jest konsensus zasad monitorowania rozwoju fizycznego dzieci?
}

\author{
${ }^{1}$ Laboratory of Anthropology, The Children's Memorial Health Institute, Warsaw, Poland \\ 2 Department of Paediatrics and Endocrinology, Medical University of Warsaw, Warsaw, Poland \\ ${ }^{3}$ Department of Paediatrics, Medical University of Warsaw, Warsaw, Poland \\ Correspondence: Piotr Dziechciarz, Paediatric Hospital of the Medical University ofWarsaw, Żwirki i Wigury 63A, 02-091 Warsaw, Poland, e-mail: piotr.dziechciarz@wum.edu.pl
}

\begin{abstract}
Regular, long-term anthropometric follow-up is one of the fundamental methods of assessing the child's health and well-being. However, there is still a lot of inconsistency in anthropometric practices and standards that may have a negative impact on clinical practice (e.g. delay in diagnosing children with growth or feeding disorders, genetic and metabolic syndromes). The paper discusses the principles of basic measurements: length/height, body weight, circumferences: head, chest and arm. Attention was also paid to the use of professional anthropometric equipment. Appropriately performed measurements allow the calculation of weight-height indices, which define nutrition disturbances (overweight, obesity and malnutrition), and also constitute the basis for conducting specialised diagnostics. In 2011, a group of experts recommended standards of body length/height, body weight, head circumference and body mass index developed by the World Health Organization for children up to 5 years of age. In 2013, nationwide reference values for weight, height and body mass index for children aged from 3 to 6 years were published and accepted as valid (OLA project). They complemented previously developed percentile charts for children aged 7-18 years (OLAF project). The paper proposes to adopt uniform standards of anthropometric measurements and to initiate a discussion in the paediatric community on the acceptance of common growth charts for the basic anthropometric measurements.
\end{abstract}

Keywords: body height, body weight, growth charts, children

Streszczenie Jedną z podstawowych metod oceny stanu zdrowia i dobrostanu dziecka jest systematyczna i długofalowa ocena antropometryczna. Nadal jednak panuje w jej zakresie dość duża dowolność praktyk i standardów, które mogą niekorzystnie wpłynąć na praktykę kliniczną, prowadząc m.in. do opóźnienia diagnozy u dzieci z zaburzeniami wzrastania, zespołami genetycznymi, metabolicznymi czy zaburzeniami karmienia. W pracy omówione zostały zasady wykonywania podstawowych pomiarów: długości i wysokości ciała, masy ciała, obwodów: głowy, klatki piersiowej i ramienia. Zwrócono również uwagę na konieczność stosowania profesjonalnego sprzętu antropometrycznego, bez którego wykonanie pomiarów jest niemożliwe. Odpowiednio przeprowadzone pomiary pozwalają bowiem na obliczenie wskaźników wagowo-wzrostowych, które definiują zaburzenia stanu odżywienia (nadwagę, otyłość i niedożywienie), a także stanowią podstawę specjalistycznej diagnostyki. W 2011 roku grupa ekspertów zarekomendowała dla dzieci do 5. roku życia standardy długości/wysokości ciała, masy ciała, obwodu głowy i wskaźnika masy ciała opracowane przez Światową Organizację Zdrowia. W 2013 roku zostały opublikowane i przyjęte jako obowiązujące ogólnopolskie wartości referencyjne masy i wysokości ciała oraz wskaźnika masy ciała dla dzieci od 3. do 6. roku życia (projekt OLA), stanowiące uzupełnienie wcześniej opracowanych siatek centylowych dla dzieci w wieku 7-18 lat (projekt OLAF). Zaproponowano przyjęcie jednolitych standardów pomiarów antropometrycznych oraz rozpoczęcie dyskusji nad przyjęciem wspólnych dla polskiego środowiska pediatrycznego siatek centylowych dla podstawowych pomiarów antropometrycznych.

Słowa kluczowe: wysokość ciała, masa ciała, siatki centylowe, dzieci 


\section{INTRODUCTION}

$\mathrm{R}$ egular, long-term anthropometric monitoring is one of the fundamental, yet often underestimated, methods of assessing the child's health and well-being. It allows for early detection of disorders that may be the first and, in some cases, the only symptom of a disease. Furthermore, slower growth and/or body weight gain are an indication for thorough diagnosis in patients with chronic, non-specific symptoms (such as recurrent abdominal pain, bone pain, rapid fatigue, and feeding disorders).

Properly performed measurements allow for the calculation of weight-growth indices, which are the basis for currently used definitions of nutritional disorders (overweight, obesity and malnutrition). Nutritional disorders require diagnosis and treatment, and when coexisting with other chronic diseases, they may contribute to complications and/or difficulties in the treatment of the underlying disease. An assessment of the nutritional status is also useful for treatment outcome evaluation an analysis of anthropometric measurements is a sensitive indicator of the efficacy of many therapies used in children ${ }^{(1)}$.

According to the common belief, medical knowledge on anthropometric measurements is complete and included in the chapters of canonical textbooks on introductory to paediatrics. In reality, however, it is difficult to find another method with so much freedom in practice or standards that would be of such importance for the clinical practice ${ }^{(2)}$. In the paediatric community, no consensus has been reached so far on some very basic issues related to anthropometric measurements:

1. what measurements, in addition to body weight and length, should be routinely performed in healthy children and with what frequency?

2. what measurement techniques should be used?

3. what equipment should be used by a paediatrician or a nurse for anthropometric measurements?

4. which growth charts should be used?

Contrary to what might seem, these are not only academic considerations as the lack of uniform principles and errors resulting from the lack of knowledge on or failure to apply anthropometric standards often delay the diagnosis and treatment or, quite the contrary, unnecessarily initiate a cascade of tests, consultations and therapies in the clinical practice, which is broadly understood as the whole of outpatient and inpatient activities. The lack of generally accepted rules also affects communication and cooperation both between doctors and between doctors and patients.

The aim of this paper is to initiate a discussion on unification of standards for monitoring child development: unifying the techniques of anthropometric measurements, adopting growth charts/standards common for the entire paediatric community, and choosing the principles for interpreting the obtained results.

\section{ASSESSMENT OF CHILD'S DEVELOPMENT}

Long-term monitoring of basic anthropometric parameters, such as body weight, body length/height, and head circumference, is performed using uniform measurement protocols. The frequency of anthropometric measurements should be adjusted to the dynamics of development. A schedule (frequency) of medical visits, including anthropometric measurements, is proposed in the new child's medical history record book. Unfortunately, the schedule assumes no measurements between 1 and 2 years of age (e.g. during vaccination at 18 months of age) and recommends only body weight and height follow-up after the age of 5 years - once every 3 years. Inadequate monitoring of physical development may delay the diagnosis of many diseases.

\section{BODY LENGTH AND HEIGHT}

The European Society for Paediatric Endocrinology lists 118 syndromes/diseases that may be accompanied by impaired body growth and at least 36 conditions characterised by excess body length ${ }^{(3)}$. These include diseases with a natural history involving a long asymptomatic phase with predominantly anthropometric clinical expression, where early diagnosis may improve the course of the disease by reducing its severity and the risk of complications. These include coeliac disease, Crohn's disease, Turner syndrome, some forms of astrocytoma and growth hormone deficiency, craniopharyngioma, juvenile nephronophthisis, and infantile cystinosis ${ }^{(4)}$.

Measurements of body height (length) are more prone to errors than those of body weight, which is due to the difficulty in measuring the youngest children (the child requires immobilisation in a certain position), lack of knowledge or ignoring of the correct measurement technique, as well as the use of inadequate anthropometric equipment.

In Poland, the measurement of body length at birth is traditionally performed along the curves of the body using an anthropometric tape. However, there is quite a lot of freedom in the technique; the measurement is usually performed from the top of the head to the foot along the curves of the body, using an anthropometric tape. This method is burdened with a large measurement error, among other things, due to the subjective choice of the point at the top of the head and the foot surface. Furthermore, it does not allow for clinical interpretation of body length at birth: plotting on the World Health Organization (WHO) growth charts, comparing this parameter with further body length measurements and, finally, assessing the nutritional status based on the body mass index (BMI) (a significant percentage of Polish newborns would be characterised by malnutrition due to their higher body length). Adoption of the WHO standards in Poland already from the child's birth should oblige neonatal units to perform body length measurements the same way as in infants and young children - 
using professional equipment (infantometer) and measuring techniques recommended in WHO protocols ${ }^{(5)}$.

Children up to 24 months of age and subjects unable to stand unassisted are measured in the supine position (body length) using the infantometer. The measurement is taken by two professionals from the top of the head (vertex point) to the plantar surface of the feet perpendicular to the lower leg, with an accuracy of $1 \mathrm{~mm}$ (Fig. 1), as follows:

1. the infantometer is placed on a hard surface (e.g. a table);

2. the child should be arranged in a supine, straightened position;

3. one person (usually the parent) holds the child's head against the stationary part of the infantometer;

4. the other person performs the measurement by gently straightening the lower limbs (in the hips and knees) and bringing the movable part of the measuring device to the child's feet (the child's head should be in the Frankfurt plane, i.e. the upper edges of the external auditory openings and the lower edge of the left orbit should be in one line perpendicular to the ground);

5. if the child is restless during the measurement and the result raises doubts, the measurement should be repeated. Body height measurement is performed in a standing position, with an accuracy of $1 \mathrm{~mm}$, using a stadiometer (a precise measuring instrument). According to WHO standards, the measurement in a standing position should be performed from 24 months of life (if the measurement was performed in a standing position before the age of 24 months, then $0.7 \mathrm{~cm}$ should be added to the length for its correct comparison with the WHO standard; similarly, if the measurement was performed in a supine position after 24 months of life, $0.7 \mathrm{~cm}$ should be subtracted from the result) ${ }^{(6)}$.

Body height measurement is performed from the basis (on which the subject stands) to the head top $(\text { vertex }-B-v)^{(7)}$. The patient should be positioned so that their body is in a straight line both in the main frontal plane, which divides the body into anterior and posterior sections, and in the median sagittal plane, which divides the body into right and left sides (which is particularly important when, e.g., measuring obese children).

A precise measurement should be performed in the morning as follows (Fig. 2):

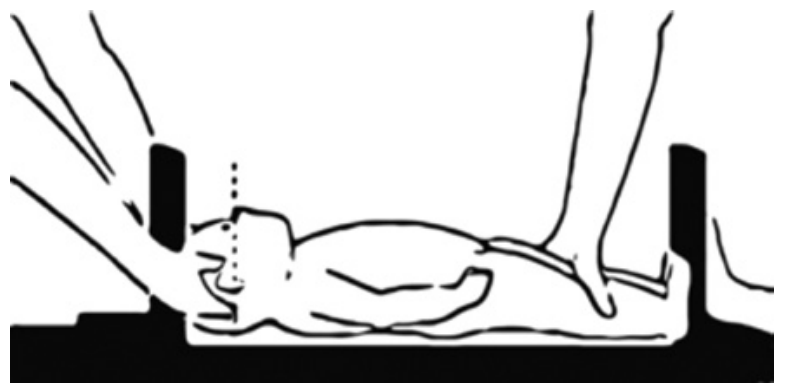

Fig. 1. A scheme of body length measurement in a child in a supine position

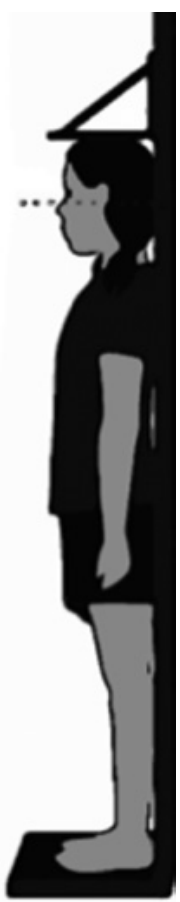

Fig. 2. A scheme of body height measurement in a child in a standing position

1. the measured participant should be in underwear, without shoes or hair ornaments (hairpins and hair bands should be removed and the hair should be let loose);

2. the participant is asked to stand with his/her back to the stadiometer, assuming an anthropometric position: arms hanging freely along the body, body weight distributed evenly on both limbs, straightened knees, head positioned in the Frankfurt plane (the lower edge of the orbit and the external auditory opening should be in one line perpendicular to the ground);

3. the head, shoulders, buttocks, and heels should be touching closely the stadiometer;

4. the operator performing the measurement lowers the sliding part of the stadiometer so as it touches the top of the participant's head (vertex point) and reads the result;

5. the measurement should be repeated 2-3 times (the participant takes several steps between measurements), and if the difference between the measurements is greater than $5 \mathrm{~mm}$, additional measurement/measurements should be performed and the average of the three most similar measurements should be taken as the result.

In special cases, such as, for example, patients with lower limb asymmetry ${ }^{(8)}$ or patients with contractures of the lower limbs and thoracic asymmetry, specific measurement techniques described in the literature should be used ${ }^{(9)}$.

\section{BODY WEIGHT}

The technique for measuring body weight is not very difficult, and weighing patients in their clothes is the most common mistake. Infants should be weighed naked or, 
optionally, in a dry diaper on a special baby scale with an accuracy of $0.01 \mathrm{~kg}$. Older children able to stand unassisted are weighed in underwear using a medical scale with an accuracy of $0.1 \mathrm{~kg}^{(10)}$. It is important that the subject stands in the centre of the scale so that the body weight is distributed evenly on both limbs. Patients unable to stand unassisted should be weighed on a chair or bed scale, possibly with a caregiver on a medical scale (the caregiver's weight is then subtracted from the combined weight). Due to fluctuations in body weight during the day, the measurement should be performed at a relatively constant time, preferably in the morning.

Individuals after amputation constitute a special group of patients. Body weight is assessed according to the principles described above; however, it is worth estimating body weight taking into account the missing limb to calculate, for example, BMI. Anthropometric tables developed by Zatsiorsky et al. ${ }^{(11)}$ and modified by de Leva ${ }^{(12)}$, which include percentages of the weight of individual body parts, are very helpful in such cases.

\section{HEAD CIRCUMFERENCE}

Despite the increasing availability of radiological imaging techniques, head circumference still remains an important measurement. It is still considered a highly useful screening tool in the diagnosis of neurological, developmental and genetic disorders. Micro- and macrocephaly are an indication for expanded diagnosis - they occur in over 500 diseases/ syndromes ${ }^{(13)}$.

Head circumference should be measured with an anthropometric tape with an accuracy of at least $0.5 \mathrm{~cm}$, through the frontal protuberances (metopion) and the external occipital protuberance (opisthocranion) ${ }^{(14)}$. The measurement methodology used by WHO differs from that adopted in Poland (measurement just above the eyebrows), which may affect the measurement result ${ }^{(15)}$.

\section{CHEST CIRCUMFERENCE}

In the nineteenth century, chest circumference was considered the third most important anthropometric measurement after body weight and height ${ }^{(16)}$. Although it is still present in the currently used child's medical history record books, it has not been included in the WHO child growth standards and there are currently no studies on the role of this parameter in child's health assessment. Nevertheless, chest circumference measurement may be useful in patients suspected of rare genetic syndromes; therefore, its should be performed as part of detailed anthropometric measurements performed by anthropologists ${ }^{(17,18)}$.

\section{MID-UPPER ARM CIRCUMFERENCE}

Mid-upper arm circumference is a parameter allowing for a relatively accurate assessment of child's nutritional status by the age of 5 years. It is one of indicators recommended by the American Society for Parenteral and Enteral Nutrition and the American Dietetic Association to assess undernutrition in children ${ }^{(19)}$. It is particularly useful in children in whom a reliable measurement of body length/height cannot be performed (e.g. with quadriplegic cerebral palsy, highly agitated or autistic), and when body weight is not an adequate indicator of nutritional status (in children with oedema, dehydration).

The measurement is performed transversely at the midlength of the arm hanging freely along the body (in the middle of the distance between the acromion and the olecranon) with an anthropometric tape with an accuracy of $0.5 \mathrm{~cm}^{(20)}$.

\section{DETAILED ANTHROPOMETRIC MEASUREMENTS}

Anthropologists who assess the physical development of children and adolescents perform measurements in accordance with the international measurement technique. Somatic measurements (including the length of the lower and upper limbs, trunk length, shoulder, hip and chest width, chest depth, waist, hip, and thigh circumference), as well as cephalometric measurements of the head and face (e.g. the length and width of the head, the smallest width of the forehead, upper and lower width of the face) are most often used in the clinical practice.

Specialised equipment used only in anthropology laboratories is used to measure body proportions. Measurements of body and head width are performed using special spreading and sliding calipers. Body proportions of the participant are standardised according to the mean and standard deviation $(S D)$ of the population. Correct developmental profile for somatic features includes a range of $0 \pm 1$ SDS (standard deviation score) $)^{(21)}$.

The identified differences in the child's physique may be helpful in certain clinical situations, e.g. in the diagnosis of Turner syndrome, Marfan syndrome, somatotropic hypopituitarism, bone dysplasia, premature/delayed puberty, and constitutional delay in growth.

Extended assessment of patient's nutritional status uses weight-growth indicators (BMI, Ponderal Index, Rohrer's Index, Quetelet's index, and Cole's index), skin-fat fold measurements (abdominal, sub-scapular and arm skinfold) as well as waist circumference measurement, which can help identify abdominal obesity. In recent years, nationwide standards for waist circumference ${ }^{(22)}$ and skin-fat folds have been published in Poland ${ }^{(23)}$.

\section{GROWTH CHARTS/DEVELOPMENTAL STANDARDS}

The choice of appropriate reference system, i.e. growth charts, arouses significant controversy in the paediatric society. Many Polish paediatricians traditionally use the 


\begin{tabular}{|c|c|c|c|}
\hline Measurement & Age & $\begin{array}{l}\text { Anthropometric } \\
\text { equipment }\end{array}$ & Comments \\
\hline \multirow{2}{*}{ Body weight } & $0-12 / 18$ months & Baby scales & $\begin{array}{l}\text { Accuracy } 0.01 \mathrm{~kg} \\
\text { Weighing capacity } 0-15 / 20 \mathrm{~kg} \\
\text { Calibration according to the manufacturer's instructions } \\
\text { Measurement in a supine or sitting position }\end{array}$ \\
\hline & $1.5-18$ years & Medical scale & $\begin{array}{l}\text { Minimal accuracy } 0.1 \mathrm{~kg} \\
\text { Weighing capacity } 150-200 \mathrm{~kg} \\
\text { Calibration according to the manufacturer's instructions } \\
\text { Measurement in a standing position }\end{array}$ \\
\hline Body length & $0-2$ years & $\begin{array}{l}\text { Infantometer } \\
\text { Liberometer* }\end{array}$ & $\begin{array}{l}\text { Accuracy } 1 \mathrm{~mm} \\
\text { Range } 80-100 \mathrm{~cm} \\
\text { Measurement in a supine position }\end{array}$ \\
\hline Height & $2-18$ years & Stadiometer & $\begin{array}{l}\text { Accuracy } 1 \mathrm{~mm} \\
\text { Range } 200-220 \mathrm{~cm} \\
\text { Stationary (wall-mounted) - calibration according to the manufacturer's instructions, } \\
\text { recommended maintenance every } 3-5 \text { years, depending on the frequency of use, } \\
\text { in an authorised service station } \\
\text { Portable - must be assembled according to the manufacturer's instructions (elements } \\
\text { in the correct order), no servicing required }\end{array}$ \\
\hline $\begin{array}{l}\text { Head circumference } \\
\text { Body circumferences }\end{array}$ & $0-18$ years & Anthropometric tape & $\begin{array}{l}\text { Accuracy } 1 \mathrm{~mm} \\
\text { Range } 150-200 \mathrm{~cm} \\
\text { Replacement depending on the frequency of use (at the first signs of wear, such as stretching, } \\
\text { folding) }\end{array}$ \\
\hline
\end{tabular}

Tab. 1. Anthropometric equipment for anthropometric measurements

so-called Warsaw growth charts (IMiD 1999), developed over 20 years ago ${ }^{(24)}$.

In 2011, a group of experts (paediatricians and anthropologists) recommended WHO standards for the monitoring of physical development in children up to 5 years of age, which reflect the development of children in optimal environmental conditions. Nationwide reference body weight, height and BMI values for children between 3 and 6 years of age (OLA Project) ${ }^{(25)}$ were published in Poland in 2013 as a supplement to the previously published nationwide growth charts for children aged between 7 and 18 years (OLAF Project) ${ }^{(26)}$.

These percentile charts/growth standards are not compatible with each other - it is not uncommon for a child's height assessed based on the WHO charts to fall within the normal range and, at the same time, to indicate an incorrect growth variant according to the national references. This is not specific for Poland as it is discussed in many countries which growth charts should be used in clinical practice. Although WHO standards have been adopted by about 150 countries in recent years, a growing number of European centres indicate that they are suboptimal for the diagnosis of growth deficiency, macro- and microcephaly, as well as for assessing birth weight, and finally for determining the obesity cutoff point compared to national growth charts ${ }^{(27)}$. The child's medical history record books introduced in January 2016 include WHO body weight and head circumference standards for children aged between 0 and 36 months. They are pre- rather than percentiles that would be easier to interpret for paediatricians and parents and comparable to the values given in the growth charts for children aged 3-18 years. Furthermore, no body length percentile charts for children under 3 years of age were included. The lack of reference for such an important parameter as body length may prevent the diagnosis of growth disorders in infants and small children.

Reference BMI curves for boys and girls between 3 and 18 years of age have been included in child's medical history record books. It may be unclear for those who do not follow auxological literature why 3 different measures overlap percentiles, standard deviations and cut-off points developed by Cole with a group of experts from the International Obesity Task Force. The latter biological reference system has been developed based on the measurements of children and adolescents in 6 countries (Brazil, UK, Netherlands, Hong Kong, Singapore and USA), and statistical methods so as it would be harmonised with the criteria for nutritional disorders in adults ${ }^{(28)}$. Unfortunately, BMI percentile charts presented in this way are unclear and unreadable for the average user, and indicate the need to develop a consensus on how to define nutritional disorders in children.

Controversies are also raised by the use of growth charts in premature infants - Polish growth charts developed 25 years ago are still used occasionally; however, two standards are currently used in practice to assess premature infants: Fenton growth charts ${ }^{(29)}$ (recommended by the Polish Neonatal Society) and Intergrowth-21 charts, which are 
constructed similar to WHO standards for term infants ${ }^{(30)}$. It seems that the latter charts should be used as the standard of choice due to their greater representativeness and compliance with WHO growth charts.

There are also available growth charts (usually for body height) for various genetic syndromes and conditions, which allow for an assessment of a child with a specific disease compared to other children with the same diagnosis. These charts are not as representative as the growth standards for healthy children due to methodological limitations (often a small number of measurements, inclusion of children with other comorbidities, imperfect statistical methods, no description of the methodology used); therefore, they should not be treated as a standard, but only as a reference.

\section{ANTHROPOMETRIC EQUIPMENT}

Reliable and accurate anthropometric measurements are impossible without proper equipment. In recent years, the old and, often, decalibrated scales have been replaced by precise electronic equipment. Unfortunately, tools that do not guarantee reliability, such as tapes, height measuring posters to be attached to the wall, measuring devices attached to scales, are still used for body length/height measurements. Errors in anthropometric measurements are unavoidable for obvious reasons. Therefore, special attention should be paid to every aspect of data collection and analysis. Providing appropriate anthropometric equipment, technically efficient and calibrated in accordance with the manufacturer's instructions, is as important as measuring patients according to the current protocols (Tab. 1).

\section{CONCLUSIONS}

It would be a truism to say that many important diagnostic and therapeutic decisions are made based on anthropometric measurements, and reliable measurements are an indispensable mainstay of good practice. However, it should be remembered that long-term monitoring is only one of many methods for assessing child's health. The results of anthropometric measurements should not be taken for granted, but should be analysed in the context of a thorough physical examination and medical history, dietary assessment and, optionally, laboratory tests, especially in cases of exceeded reference values.

For obvious reasons, we do not claim the right to formulate any recommendations. However, we encourage organisation and standardisation of practices related to an auxological assessment of a child. We believe that it is necessary to resume discussion among the representatives of all scientific associations dealing with child's health on the development of standards for anthropometric measurements under the patronage of the National Consultant in the field of Paediatrics and the Polish Society of Anthropology.
We are also aware that even the most reliable measurement protocols established in accordance with the latest research will remain only paper proclamations without the joint effort of all those involved in child health care. Overcoming routine, changing habits, awareness of the importance of reliable measurements, and, finally, education and supervision over operators performing these measurement are necessary for the effective implementation of all recommendations.

\section{Conflict of interest}

Authors do not report any financial or personal connections with other persons or organisations, which might negatively affect the contents of this publication and/or claim authorship rights to this publication.

\section{References}

1. Dziechciarz P: Ocena stanu odżywienia. In: Szajewska H, Horvath A (eds.): Żywienie i leczenie żywieniowe dzieci i młodzieży. Medycyna Praktyczna, Kraków 2017: 7-14.

2. Carsley S, Birken CS, Tu K et al.: Examining growth monitoring practices for children in primary care. Arch Dis Child 2018; 103: 406-407.

3. International Classification of Pediatric Endocrine Diagnoses. Available from: http://www.icped.org/.

4. Scherdel P, Reynaud R, Pietrement C et al.; EBGM III study group: Priority target conditions for algorithms for monitoring children's growth: interdisciplinary consensus. PLoS One 2017; 12: e0176464.

5. Training Course on Child Growth Assessment. WHO Child Growth Standards. Measuring a Child's Growth. World Health Organization, Geneva 2008. Available from: http://www.who.int/ childgrowth/training/module_b_measuring_growth.pdf.

6. de Onis M, Onyango AW, Van den Broeck J et al.: Measurement and standardization protocols for anthropometry used in the construction of a new international growth reference. Food Nutr Bull 2004; 25 Suppl 1: S27-S36.

7. Malinowski A: Definicje punktów antropometrycznych. In: Malinowski A, Bożiłow B (eds.): Podstawy antropometrii. Metody, techniki, normy. Wydawnictwo Naukowe PWN, Warszawa Łódź 1997: 80-85.

8. Sabharwal S, Kumar A: Methods for assessing leg length discrepancy. Clin Orthop Relat Res 2008; 466: 2910-2922.

9. Świąder-Leśniak A: Jak zmierzyć i zważyć pacjenta? Trudne przypadki w diagnostyce klinicznej. Stand Med Pediatr 2017; 14: 85-90.

10. Kułaga Z, Świąder-Leśniak A, Litwin M: Antropometryczne wskaźniki rozwoju i stanu odżywienia. In: Socha P, Lebensztejn D, Lifschitz C et al. (eds.): Gastroenterologia dziecięca - podręcznik do specjalizacji. Media-Press, Warszawa 2016: 399-408.

11. Zatsiorsky VM, Seluyanov VN, Chugunova LG: Methods of determining mass-inertial characteristics of human body segments. In: Chemyi GG, Regirer SA (eds.): Contemporary Problems of Biomechanics. CRC Press, Massachusetts 1990: 272-291.

12. de Leva P: Adjustments to Zatsiorsky-Seluyanov's segment inertia parameters. J Biomech 1996; 29: 1223-1230.

13. Rollins JD, Collins JS, Holden KR: United States head circumference growth reference charts: birth to 21 years. J Pediatr 2010; 156: 907-913.

14. Łaska-Mierzejewska T: Antropometria i antroposkopia. In: Charzewski J, Lewandowska J, Łaska-Mierzejewska T et al.: Antropologia. AWF, Warszawa 2004: 233-254.

15. Training Course and Other Lots. WHO Child Growth Standards. World Health Organization, Geneva 2008. Available from: https://www.who.int/childgrowth/training/en/.

16. Accardo PJ, Jaworski M: Heads up: plotting children's head circumference. J Pediatr 2010; 156: 871-872. 
17. Walczak-Sztulpa J, Wawrocka A, Sobierajewicz A et al.: Intrafamilial phenotypic variability in a Polish family with Sensenbrenner syndrome and biallelic WDR35 mutations. Am J Med Genet 2017; 173: 1364-1368.

18. Malinowski A: Pomiary antropologiczne. In: Malinowski A, Wolański N (eds.): Metody badań w biologii człowieka. Wybór metod antropologicznych. PWN, Warszawa 1988: 119-157.

19. Becker P, Carney LN, Corkins MR et al.; Academy of Nutrition and Dietetics; American Society for Parenteral and Enteral Nutrition: Consensus statement of the Academy of Nutrition and Dietetics/American Society for Parenteral and Enteral Nutrition: indicators recommended for the identification and documentation of pediatric malnutrition (undernutrition). Nutr Clin Pract 2015; 30: 147-161.

20. Frisancho AR: New norms of upper limb fat and muscle areas for assessment of nutritional status. Am J Clin Nutr 1981; 34: 2540-2545.

21. Majcher A, Pyrżak B: Antropologiczne metody oceny rozwoju fizycznego. In: Pyrżak B, Walczak M (eds.): Endokrynologia wieku rozwojowego. PZWL, Warszawa 2018: 953-975.

22. Świąder-Leśniak A, Kułaga Z, Grajda A et al.: Wartości referencyjne obwodu talii i bioder polskich dzieci i młodzieży w wieku 3-18 lat. Stand Med Pediatr 2015; 12: 137-150.

23. Jaworski M, Kułaga Z, Płudowski P et al.; the Olaf Study Group: Population-based centile curves for triceps, subscapular and abdominal skinfold thicknesses in Polish children and adolescents - the OLAF study. Eur J Pediatr 2012; 171: 1215-1221.

24. Palczewska I, Niedźwiecka Z: Wskaźniki rozwoju somatycznego dzieci i młodzieży warszawskiej. Med Wieku Rozw 2001; 5 Suppl 1: $18-118$.

25. Kułaga Z, Grajda A, Gurzkowska B et al.: Polish 2012 growth references for preschool children. Eur J Pediatr 2013; 172: 753-761.

26. Kułaga Z, Litwin M, Tkaczyk M et al.: Polish 2010 growth references for school-aged children and adolescents. Eur J Pediatr 2011; 170: 599-609.

27. Christesen HT, Pedersen BT, Pournara E et al.: Short Stature: Comparison of WHO and National Growth Standards/References for Height. PLoS One 2016; 11: e0157277.

28. Cole TJ, Bellizzi MC, Flegal KM et al.: Establishing a standard definition for child overweight and obesity worldwide: international survey. BMJ 2000; 320: 1240-1243.

29. Fenton TR, Kim JH: A systematic review and meta-analysis to revise the Fenton growth chart for preterm infants. BMC Pediatr 2013; 13: 59.

30. Villar J, Giuliani F, Bhutta ZA et al.; International Fetal and Newborn Growth Consortium for the $21^{\text {st }}$ Century (INTERGROWTH-21 $1^{\text {st }}$ ): Postnatal growth standards for preterm infants: the Preterm Postnatal Follow-up Study of the INTERGROWTH-2 $1^{\text {st }}$ Project. Lancet Glob Health 2015; 3: e681-e691. 